\title{
Kajian Hukum Tentang Internet Mobile dalam Upaya Pencegahan Dampak Negatif Teknologi Informasi dan Komunikasi di Indonesia
}

\author{
Dudi Badruzaman \\ Sekolah Tinggi Agama Islam (STAI) Sabili, Bandung. \\ Email : badruzaman.dudi@yahoo.com
}

\section{Info Artikel:}

| Diterima: 7 September 2019

| Disetujui: 30 Desember 2019

| Dipublikasikan: 31 Desember 2019

\begin{abstract}
The development of information technology is not only able to create a global world but also has developed a space for new life for society, namely the life of a virtual society. But it is not denied that not all internet activities are always positively charged, but the internet also has a negative side, so from that there must be a more effective and preventive negative impact of information technology. The purpose of this study are: 1) To determine the negative impact of mobile internet use in Indonesia. 2) To find out about legal efforts to prevent the negative impact of information technology in Indonesia. 3) To find out sanctions and regulations that can be used to ensnare the perpetrators of abuse of mobile internet in Indonesia. This study uses a normative juridical approach the method used is a qualitative method, the data source in this study consists of primary, secondary and tertiary. Data analysis is done by reviewing, interpreting the collected data to draw a conclusion and using a field approach, namely by conducting discussions on internet crime cases. So that a conclusion can be obtained as an answer to the problems discussed in this study.
\end{abstract}

Keywords: internet; mobile, prevention; technology.

\begin{abstract}
Abstrak
Perkembangan teknologi informasi tidak saja mampu menciptakan dunia global namun juga telah mengembangkan ruang gerak kehidupan baru bagi masyarakat yaitu kehidupan masyarakat maya. Namun tidak di pungkiri bahwa tidak semua aktifitas internet selalu bermuatan positif tetapi internet juga memiliki sisi negatif, Maka dari hal itu harus ada penanggulangan dampak negatif teknologi informasi yang lebih efektif dan bersifat preventif. Tujuan penelitian ini adalah: 1) Untuk mengetahui dampak negatif penggunaan internet mobile di Indonesia. 2) Untuk mengetahui upaya hukum pencegahan dampak negatif teknologi informasi di Indonesia. 3) Untuk mengetahui sanksi dan peraturan yang dapat digunakan untuk menjerat pelaku penyalahgunaan internet mobile di indonesia. Penelitian ini menggunakan pendekatan yuridis normatif metode yang di gunakan adalah metode kualitatif, sumber data dalam penelitian ini terdiri dari primer, skunder dan tertier. Analisis data di lakukan dengan cara mengkaji, menafsirkan data-data yang sudah terkumpul untuk menarik sebuah kesimpulan penilitian seta menggunakan pendekatan lapangan yakni dengan melakukan pembahasan terhadap kasus kejahatan internet. Sehingga dapat diperoleh suatu kesimpulan sebagai jawaban atas permasalahan yang di bahas dalam penelitian ini.
\end{abstract}

Kata Kunci : internet mobile; pencegahan; teknologi. 


\section{A. PENDAHULUAN}

Kemajuan ilmu pengetahuan dan teknologi telah mendorong perkembangan masyarakat ke arah kehidupan yang lebih modern, karena penggunaan teknologi selalu mempengaruhi pola pikir dan gaya hidup masyarakat. Suatu teknologi pada dasarnya diciptakan untuk peningkatan kualitas hidup dan mempermudah aktivitas manusia menjadi lebih efektif dan efisien. Namun tidak dapat dipungkiri bahwa selain memiliki sisi positif, teknologi juga memiliki sisi negatif.

Bahkan dalam berbagai kajian penelitian, kemajuan teknologi menunjukkan korelasi yang positif terhadap meningkatnya angka kriminalitas, misalnya dalam masyarakat maya, metode kehidupannya tidaklah jauh berbeda dengan kehidupan nyata, ada proses sosial, interaksi sosial, kontrol sosial, komunikasi, membangun kebudayaan, bahkan pengembangan sistem kejahatan dan lain-lain. Internet mobile memberikan berbagai kemudahan dalam banyak aspek kehidupan manusia karena telah mengubah jarak dan waktu menjadi tanpa batas. Adanya fasilitas chatting, e-mail dan web-cam merupakan solusi dari permasalahan penggunaan komputer. Sikap ketergantungan, keteledoran, kekurangpahaman atau kesengajaan dalam menggunakan komputer akan menimbulkan dampak negatif, bilamana tidak diimbangi dengan sikap mental dan sikap tindak positif. ${ }^{1}$

Salah satu hasil kemajuan teknologi informasi yang diciptakan pada akhir abad ke20 adalah Internet. Teknologi internet membawa manusia pada peradaban baru, dimana terjadi perpindahan realitas kehidupan dari aktivitas. nyata ke aktivitas maya (virtual) yang disebut dengan istilah cyberspace. Perkembangan teknologi informasi tidak saja mampu menciptakan dunia global, namun juga telah mengembangkan ruang gerak kehidupan baru bagi masyarakat, yaitu kehidupan masyarakat

\footnotetext{
1 Widyopramono, Kejahatan di Bidang Komputer, (Jakarta: Pustaka Sinar Harapan, 2012), hlm. 28.
}

maya (cybercommunity). Cybercommunity adalah sebuah kehidupan masyarakat manusia yang tidak dapat secara langsung diindera melalui penginderaan manusia, namun dapat dirasakan dan disaksikan sebagai sebuah realitas. $^{2}$

Salah satu masalah cyber crime yang juga sangat meresahkan dan mendapat perhatian berbagai kalangan adalah masalah cyber crime di bidang cyber pornography (khususnya child pornography) dan cyber sex. Permasalahan ini juga mendapat perhatian serius dari dunia internasional,yaitu dengan adanya The first World Congress Against Commercial Sexual Exploitation of Children, Stockholm, 27 - 31 Agustus 1996 dan International Conference on "Combatting Child Pornography on the Internet", Vienna, Hofburg, pada tanggal 29 September - 1 $\begin{array}{lll}\text { Oktober } & 1999 . & \text { Dalam situs }\end{array}$ www.computeruser.com, cyberporn didefinisikan sebagai "materi pornografi yang tersedia online" ("Pornographic material available online”).

Materi-materi pornografi di internet sangatlah banyak dan mudah untuk ditemukan. Catherine MacKinnon menyatakan bahwa "Pornografi di dunia maya adalah pornografi dalam lingkup lebih luas, lebih dalam, lebih buruk, dan lebih banyak" ("Pornography in cyberspace is pornography in society-justbroader, deeper, worse, and more of it. Menurut perkiraan, $40 \%$ dari berbagai situs menyediakan bahan-bahan seperti itu. American Demographics Magazine dalam laporannya menyatakan bahwa jumlah situs pornografi meningkat dari 22.100 pada tahun 1997 menjadi 280.300 pada tahun 2000 atau melonjak 10 kali lebih dalam kurun waktu tiga tahun.

Menjamurnya situs-situs porno ini disebabkan oleh besarnya keuntungan kesusilaan. Jenis cyber crime di bidang

\footnotetext{
2 M.Burhan Bungin, Pornomedia "Sosiologi Media, Konstruksi Sosial Teknologi Telematika dan Perayaan Seks di Media Massa", (Jakarta: Prenada Media, 2011), hlm. 27.
} 
kesusilaan yang sering diungkapkan finansial yang diperoleh dari bisnis ini. Saat ini beberapa negara telah mengambil langkah kebijakan hukum dengan membuat undangundang yang dapat menjerat pelaku cyber crime. Mengingat dampak negatif dari internet bukan hanya menyangkut permasalahan moral, budaya dan HAM, tetapi juga masalah ekonomi-bisnis, hiburan (entertainment) dan politik. Oleh karena itu harus harus ada pengaturan khusus untuk menangkal dampak negatif dari multiproblem tersebut.

\section{B. METODE PENELITIAN}

Permasalahan utama dalam penelitian ini adalah kajian hukum tentang internet mobile dalam upaya pencegahan dampak negatif teknologi informasi dan komunikasi di indonesia. karena itu pendekatan yang digunakan terhadap masalah ini tidak dapat terlepas dari pendekatan yang berorientasi pada kebijakan. Pendekatan kebijakan mencakup pengertian yang saling tali menali antara pendekatan yang berorientasi pada tujuan, pendekatan yang rasional, pendekatan ekonomis dan pragmatis, serta pendekatan yang berorientasi pada nilai. Penelitian ini difokuskan pada penelitian terhadap substansi hukum yang berkaitan dengan internet mobile, baik hukum positif yang berlaku sekarang (ius constitutum) maupun hukum yang dicita-citakan (iusconstituendum).

Penelitian tentang internet mobile dalam upaya pencegahan dampak negatif teknologi informasi dan komunikasi di indonesiaini menggunakan pendekatan yang bersifat yuridis normatif, yaitu dengan mengkaji/menganalisis data sekunder yang berupa bahan-bahan hukum terutama bahan hukum primer dan bahan hukum sekunder, dengan memahami hukum sebagai seperangkat peraturan atau norma-norma positif di dalam sistem perundang-undangan yang mengatur mengenai kehidupan manusia.

Penelitian hukum normatif merupakan penelitian yang dilakukan dengan cara meneliti bahan pustaka. Menurut Soerjono
Soekanto dan Sri Mamuji, penelitian hukum normatif mencakup : (1) penelitian terhadap asas-asas hukum; (2) penelitian terhadap sistematik hukum; (3) penelitian terhadap taraf sinkronisasi vertikal dan horizontal; (4) perbandingan hukum; dan (5) sejarah hukum. ${ }^{3}$

Sementara menurut Ronny Hanitijo Soemitro, penelitian hukum normatif juga meliputi penelitian pada point (1), (2) dan (3) tersebut, namun 2 (dua) bentuk penelitian lainnya berbeda, yaitu penelitian untuk menemukan hukum in concrito dan penelitian inventarisasi hukum positif. Penelitian dalam tesis ini menitikberatkan pada penelitian terhadap asas-asas hukum, sistematik hukum, taraf sinkronisasi vertikal dan horizontal, perbandingan hukum dan inventarisasi hukum positif. Adanya pendekatan perbandingan hukum, diperlukan untuk memberikan gambaran dan masukan bagi kebijakan formulasi hukum pidana yang sebaiknya dirumuskan. Dalam perbandingan hukum antar beberapa negara harus mengungkapkan persamaan dan perbedaannya walaupun dari segi perkembangan ekonomi dan politik mungkin berbeda. ${ }^{4}$

Spesifikasi dalam penelitian ini adalah penelitian deskriptif analitis, yaitu penelitian yang mendeskriptifkan secara terperinci hasil analisis mengenai asas-asas hukum, sistematik hukum, taraf sinkronisasi vertikal dan horizontal, perbandingan hukum dan inventarisasi hukum positif. Suatu penelitian deskriptif dimaksudkan untuk memberikan data yang seteliti mungkin tentang manusia, keadaan atau gejala-gejala lainnya. ${ }^{5}$

Penelitian hukum yang bersifat normatif selalu menitikberatkan pada sumber data sekunder. Data sekunder pada penelitian dapat dibedakan menjadi bahan-bahan hukum primer, bahan hukum sekunder dan bahan

\footnotetext{
3 Soerjono Soekanto dan Sri Mamuji, Penelitian Hukum Normatif "Suatu Tinjauan Singkat",(Jakarta: Raja Grafindo Persada, 2012), hlm.15.

4 Peter Mahmud Marzuki, Penelitian hukum, (Jakarta: Prenada Media, 2013), hlm. 135.

5 Soerjono Soekanto, Pengantar Penelitian hukum, (Jakarta: UI Press, 2017), hlm.13.
} 
hukum tertier. Dalam penelitian ini, bersumber dari data sekunder sebagai berikut

a. Bahan hukum primer, yaitu bahan-bahan hukum yang mengikat, seperti KUHP Indonesia dan KUHP beberapa negara asing serta peraturan perundang-undangan di luar KUHP yang berkaitan dengan permasalahan intenet mobile ;

b. Bahan hukum sekunder, yang memberikan penjelasan mengenai bahan hukum primer, seperti Konsep KUHP tahun 2005, Rancangan Undang-undang Pemanfataan Teknologi Informasi (RUU PTI), Rancangan Undang-undang Anti Pornografi dan Pornoaksi (RUU APP), hasil penelitian dan karya ilmiah;

c. Bahan hukum tertier, yakni bahan yang memberikan petunjuk maupun penjelasan terhadap bahan hukum primer dan sekunder, seperti Kamus Besar Bahasa Indonesia, kamus bahasa Inggris, kamus istilah komputer dan internet dan kamus hukum.

Metode pengumpulan data yang digunakan dalam suatu penelitian pada dasarnya tergantung pada ruang lingkup dan tujuan penelitian. Menurut Ronny Hanitijo Soemitro, teknik pengumpulan data terdiri dari studi kepustakaan, pengamatan (observasi), wawancara (interview) dan penggunaan daftar pertanyaan (kuisioner). Berdasarkan ruang lingkup, tujuan dan pendekatan dalam penelitian ini, maka teknik pengumpulan data yang digunakan adalah studi kepustakaan dan dokumenter dari data skunder yang telah dianalisis.

Berdasarkan rumusan masalah dan tujuan penelitian, maka analisis data dilakukan secara normatif kualitatif. Kajian normatif berupa analisis kebijakan formulasi hukum pidana saat ini maupun yang akan datang, dalam dalam KUHP maupun di luar KUHP. Kajian normatif ini juga harus didukung dengan kajian komparatif, sedangkan kualitatif merupakan analisis asasasas hukum yang ada, apakah saling berhubungan satu sama lain.

\section{HASIL DAN PEMBAHASAN}

\section{Perkembangan Teknologi Informasi dalam Tatanan Global}

Internet merupakan sebuah kumpulan global (mendunia) ribuan jaringan komputer dan jutaan komputer pribadi yang dikelola secara bebas. Internet telah memungkinkan komunikasi antar computer dengan menggunakan Transmission Control Protocol atau internet protocol (TCL/IP) tang didukung media komunikasi, seperti satelit dan paket radio. TCP/IP ibarat bahasa yang di mengerti oleh semua jenis komputer sehingga antar komputer dapat saling berkomunikasi tanpa protocol. Komputer tidak akan dapat berkomunikasi di internet. Internet dapat menghubungkan komputer dan jaringan komputer yang dikelolam baik oleh pemerintah maupun swasta dan perorangan yang ada di berbagai Negara melalui internet. Siapapun dan kapan pun dapat leluasa mengakses berbagai macam informasi dari berbagai tempat. Informasi yang dapat di akses tampak lebih hidup karena tersaji dalam bentuk teks, grafik, animasi, suara, maupun video. Selain itu informasi yang tersedia sangat bervariasi dan selalu aktual.

Mobile web bertujuan untuk mengakses layanan data secara wireless dengan menggunakan perangkat mobile seperti handphone, dan perangkat portable yang tersambung ke sebuah jaringan telekomunikasi selular. Mobile web yang diakses melalui perangkat mobile perlu dirancang dengan mempertimbangkan keterbatasan perangkat mobile seperti sebuah handphone yang memiliki sebuah layar dengan ukuran yang terbatas 
ataupun beberapa keterbatasan pada sebuah perangkat mobile.

Pada Mei 2005 mobile web di keluarkan oleh W3C dengan nama Mobile Web Initiative (MWI) dengan tujuan membuat web dapat diakses dari sebuah perangkat mobile secara sederhana seperti mengakses web dari sebuah komputer desktop. Dalam membuat sebuah mobile web membutuhkan implementasi untuk perbaikan dari segi interoperability, usebility dan accessibility pada sebuah mobile web. Mobile Web umumnya berukuran ringan disetiap halamannya yang ditulis dengan Extensible Hypertext Markup Language (XHTML) atau Wireless Markup Language (WML) untuk mengirimkan konten ke perangkat mobile. Selain itu beberapa teknik seperti dengan menggunakan Adobe Flash Lite atau Sun's J2ME yang memungkinkan untuk membuat perangkat mobile yang lebih bervariasi. Keterbatasan dari kecepatan processor dalam mengeksekusi proses:

\section{Keterbatasan RAM}

2. Ukuran layar yang tidak terlalu besar, dan juga perbedaan ukuran layar secara fisik dan resolusi pada masing-masing perangkat (meskipun saat ini tersedia browser seperti Opera yang dapat menampilkan seluruh halaman seperti browser pada PC).

3. Keterbatasan input pada masing-masing perangkat mobile.

4. Ketahanan baterai yang berbeda pada setiap perangkat.

5. Selain itu dari segi software, kompatibilitas browser dan mobiles pendukung cukup berpengaruh dalam

menjalankan sebuah mobile web.

Adanya teknologi internet berawal dari perkembangan teknologi komputer dan telekomunikasi. Perpaduan kedua teknologi ini telah memunculkan suatu teknologi baru yang dikenal dengan internet. Berawal dari rangkaian beberapa komputer dari suatu tempat atau ruangan atau gedung yang disebut dengan LAN (Local Area Network), sementara di gedung lain ada lagi LAN. Jika beberapa LAN ini digabung atau dirangkaikan menjadi satu akhirnya menjadi kelompok LAN yang disebut WAN (Wide Area Network). Beberapa WAN ini dapat dirangkai menjadi WAN lagi yang lebih besar dan banyak serta bukan saja berhubungan antar gedung tetapi juga menjadi antar kota, antar provinsi bahkan antar negara yang terangkai menjadi satu, maka disebutlah internet. $^{6}$

Sejarah intenet dapat dibagi dalam 4 (empat) aspek, yaitu : ${ }^{7}$

1. Adanya aspek evolusi teknologi yang dimulai dari riset packetswitching (paket pensaklaran) ARPANET (berikut teknologi perlengkapannya) yang pada saat itu dilakukan riset lanjutan untuk mengembangkan wawasan terhadap infrastruktur komunikasi data yang meliputi beberapa dimensi seperti skala, performance/kehandalan, dan kefungsian tingkat tinggi;

\footnotetext{
${ }^{6}$ Al Wisnubroto,Kebijakan Hukum Pidana Dalam Penanggulangan Kejahatan Komputer, (Yogyakarta, Penerbit Universitas Atmajaya, 1999), hlm. 104.

7 Artikel dalam jurnal: Barry M. Leiner "A Brief History of Internet", 876 (2014):521
} 
2. Adanya aspek pelaksanaan dan pengelolaan sebuah infrastruktur yang global dan kompleks;

3. Adanya aspek sosial yang dihasilkan dalam sebuah komunitas masyarakat besar yang terdiri dari para Internauts yang bekerjasama membuat dan mengembangkan terus teknologi ini;

4. Adanya aspek komersial yang dihasilkan dalam sebuah perubahan ekstrim namun efektif dari sebuah penelitian yang mengakibatkan terbentuknya sebuah infrastruktur informasi yang besar dan berguna.

Cikal bakal internet pertama kali dikembangkan pada tahun 1969 oleh Departemen Pertahanan Amerika Serikat dengan nama ARPAnet (United States Department of Defense Advanced Research Projects Agency). ARPAnet dibangun dengan sasaran untuk membuat suatu jaringan komputer yang tersebar, untuk menghindari pemusatan informasi disatu titik yang dipandang rawan untuk dihancurkan apabila terjadi peperangan. Pada tanggal 1 Januari1983, ARPANET menukar protokol rangkaian pusatnya, dari NCP kepada TCP/IP. Ini merupakan permulaan Internet yang kita kenali hari ini.

Pada mulanya jaringan interkoneksi ini disebut DARPA Internet, namun kemudian hanya disebut dengan internet saja. Pada awal perkembangannya, internet hanya menawarkan layanan berbasis teks saja, seperti remote access, $e$ mail/messaging, maupun diskusi melalui News group (usenet). Layanan berbasis grafis seperti $w w w$ saat itu masih belum ada.

Pada awalnya internet lebih banyak dipergunakan untuk kepentingan akademis dengan menghubungkannya pada beberapa perguruan tinggi, seperti UCLA, University California at Santa Barabara, University of Utah dan Stanford Research Institute. Namun setelah dibuka layanan Usenet dan Bitnet, internet dapat diakses melalui sarana komputer pribadi (personal computer). Saat ini jaringan internet telah menjangkau hampir seratus negara di dunia. Internet menjadi kebutuhan teknologi yang digunakan dan terus dikembangkan, baik di negara maju maupun negara yang sedang berkembang. Di negara-negara maju, internet bukan lagi sebagai media baru, tetapi telah menjadi kebutuhan beraktivitas. Hal ini sesuai dengan pernyataan teoritikus internet, Nicholas Negroponte, bahwa revolusi digital telah berakhir, dan internet telah menjadi teknologi sehari-hari dan bukan sesuatu yang luar biasa atau aneh. ${ }^{8}$

Pada era pemerintahan Presiden Bill Clinton, Pemerintahan Amerika Serikat menghadiahkan hubungan internet kepada 2000-an sekolah menengah di California. Kebijakan ini bertujuan agar penduduk Amerika Serikat ditahuntahun mendatang diharapkan telah memiliki paling tidak fasilitas surat elektronik. ${ }^{9}$ Pada masa ini Amerika Serikat telah berupaya agar warganya bebas dari kebutaan terhadap internet, tetapi Indonesia

\footnotetext{
${ }^{8}$ Gary R. Bunt danLampeter, Islam Virtual : Menjelajah Islam di Jagad Maya, (Yogyakarta, Suluh Press, 2005), hlm. 221.

${ }^{9}$ Budi Agus Riswandi, Hukum Dan Internet Di Indonesia, (Yogyakarta, UII Press, 2003), hlm.13.
} 
sampai dengan sekarang masih pada kebijakan pemberantasan buta aksara. Jaringan internet di Indonesia mulai dikembangkan pada awal tahun 1990 oleh UI, ITB, LAPAN dan BPPT serta Paguyuban Teknologi Packet Radio sebagai basis untuk network regional. Pada tahun 1994 muncul Indo internet (INDONET) yang dipimpin oleh Sanjaya sebagai ISP komersial pertama di Indonesia. Bisnis internet terus berkembang dan ada sekitar 60an ISP yang memperoleh lisensi dari pemerintah. ISP-ISP ini membentuk asosiasi ISP (APJII) pada tahun 1998. Efisiensi sambungan antar ISP terus dilakukan dengan membangun beberapa Internet Exchange (IX) di Indosat, Telkom, APJII (IIX) dan beberapa ISP lainnya yang saling exchange. APJII mulai melakukan manuver untuk memperbesar pangsa pasar internet di Indonesia dengan melakukan program SMU 2000 yang kemudian berkembang menjadi Sekolah 2000.

Pada awal kemunculannya di Indonesia, internet merupakan barang langka yang hanya digunakan oleh sebagian orang saja, seperti dosen, peneliti atau pejabat pemerintah. Namun dengan dimulainya layanan internet komersial di Indonesia pada awal tahun 1994, sekarang publik telah dapat mengakses internet dengan mudah dan biaya yang terjangkau. Sejak saat itu internet menjadi media bisnis baru yang komersial. Sekarang jaringan internet di Indonesia terus berkembang dan semakin luas, karena banyak perusahaan, sekolah-sekolah, kampus-kampus, bahkan di rumahrumah telah memiliki jaringan internet. Selain itu, WARNET (warung internet) sekarang mulai banyak bermunculan dan telah ada Asosiasi WARNET Indonesia yang berdiri pada tanggal 25 Mei 2000.
Pada bulan Juli tahun 2001 Tim Koordinasi Telematika Indonesia (TKTI), Kadin, Asosiasi Warnet Indonesia (Awari) dan Asosiasi Pengusaha Wartel Indonesia (APWI) meluncurkan program "500 ribu Warnet/Wartel" diseluruh Indonesia.

Semakin luasnya jaringan internet di Indonesia merupakan hal yang positif bagi program pemberantasan gagap teknologi (gaptek). Namun dalam kenyataannya, ternyata luasnya jaringan tidak selalu sejalan dengan meningkatnya pengguna internet. Pada tahun 2003, dari sekitar 240 juta penduduk Indonesia hanya sekitar 3 sampai 4 juta warga Indonesia saja yang menggunakan internet. Hal ini disebabkan oleh banyak faktor, salah satunya adalah minimnya sosialisasi, baik itu tentang bagaimana penggunaannya, manfaat maupun cara menghindari dampak negatifnya. Akibatnya masyarakat terlebih dahulu menghindari, menjauhi bahkan mentabukan internet, karena informasi yang diterima oleh masyarakat hanyalah hal-hal negatif saja, seperti banyaknya muatan pornografi.

Internet memiliki beberapa keistimewaan dan keunggulan yang mungkin tidak dimiliki oleh media lainnya, baik itu media massa maupun media elektronik yang telah ada sebelumnya. Ada beberapa contoh keistimewaan dan keunggulan internet, yaitu efficiency (efisiensi), without boundary (tanpa batas), 24hours on-line (terbuka 24 jam), interactive, hyperlink (terjalin dalam sekejap), no license (tak perlu izin) dan nocensorship (tanpa sensor). Keuntungan lain yang dapat dinikmati 
melalui internet adalah dari beberapa jenis layanannya, antara lain adalah $:^{10}$

1. E-Commerce, adalah aktivitas transaksi perdagangan melalui sarana internet. Di sini produk dapat ditawarkan lintas negara;

2. E-Banking, adalah aktivitas perbankan di dunia maya (virtual) melalui sarana internet. Layanan ini memungkinkan nasabah untuk melakukan berbagai transaksi seperti pengecekan saldo, transfer dana, pembayaran tagihan dan lain-lain tanpa harus pergi ke bank;

3. E-Goverment, adalah pemerintah menggunakan internet untuk memberikan berbagai informasi, seperti program kerja/kebijakan dan berbagai pelayanan umum kepada masyarakat;

4. E-Learning, adalah proses belajar mengajar di sekolah dalam bentuk digital/di dunia maya.

Hal inilah yang menyebabkan terjadinya berbagai bentuk kejahatan dan pelanggaran di dunia maya, seperti bermunculannya cybercrime, cyberporn, cybersex dan lain-lain, adanya dampak negatif cyber crime yang begitu luas, menyebabkan masyarakat internasional melakukan upaya-upaya antisipasi dan penanggulangan, seperti dalam Kongres PBB mengenai "The Prevention of crime and the Treatment of Offender. (yang diselenggarakan setiap 5 tahun) telah pula membahas

${ }^{10}$ Budi Agus Riswandi, Tindak Pidana Mengenai Kesopanan (Jakarta: RajaGrafindo Persada,2014), hlm. 15. masalah ini sampai tiga kali, yaitu pada Kongres VIII/1990 di Havana, Kongres X/2000 di Wina, dan terakhir pada Kongres XI/2005 di Bangkok (tanggal 18-25April 2005). Dalam "background paper" lokakarya "Measures to Combat Computerrelated Crime" Kongres XI PBB dinyatakan, bahwa "teknologi baru yang mendunia di bidang komunikasi dan informasi memberikan"bayangan gelap" (a dark shadow) karena memungkinkan terjadinya bentukbentuk eksploitasi baru, kesempatan baru untuk aktivitas kejahatan,dan bahkan bentuk-bentuk baru dari kejahatan.

Kekhawatiran yang sama juga terungkap dalam makalah "Cyber Crime yang disampaikan oleh Information Technology Association of Canada (ITAC) pada International Information Industry Congress (IIIC) 2000 Millenium Congress" di Quebec pada tanggal 19 September 2000, yang menyatakan bahwa "Cyber crime is a real and growing threat toeconomic and social development around the word. Informationtechnology touches every aspect of human life and so can electronicallyenable crime. ${ }^{11}$

Pernyataan ITAC ini menunjukkan bahwa cyber crime merupakan ancaman bagi perkembangan ekonomi dan sosial, bahkan setiap aspek/sendi kehidupan manusia. Hal ini dapat dilihat dengan munculnya berbagai jenis kejahatan baru. Di bidang ekonomi ada onlinebusines crime, cyber money laundring dan EFT crime. Di Bidang politik dan pertahanan ada racist propaganda, cyber terrorism dan hacker dalam perhitungan suara

\footnotetext{
11 Barda Nawawi Arief,Perkembangan Kajian Cyber Crime Di Indonesia,(Jakarta: Sinar Grafika ,2018), hlm, 2.
} 
pemilu on-line. Sementara dibidang moral adanya cyberporn dan cybersex.

Para pengguna internet beranggapan bahwa cyberspace adalah dunia global yang lepas dari batasbatas wilayah teritorial negara manapun. Padahal berbagai bentuk cyber crime telah merajalela dan merugikan banyak pihak. Sementara teori-teori jurisdiksi di atas pada dasarnya diterapkan pada wilayah teritorial negara masing-masing dengan batas-batas geografis. Oleh karena itu diperlukan adanya ketentuan jurisdiksi di ruang maya yang dapat menjangkau cyber crime.

$$
\text { Masaki Hamano dalam }
$$
tulisannya berjudul "Comparative Study in the Approach to Jurisdiction in Cyberspace",12 mengemukakan adanya jurisdiksi yang didasarkan pada prinsip-prinsip tradisional. Menurutnya ada tiga kategori jurisdiksi tradisional, yaitu :

1. Jurisdiksi legislatif ("legislative jurisdiction" atau "jurisdiction to prescribe"), yaitu kewenangan pembuatan hukum substantif;

2. Jurisdiksi judisial ("judicial jurisdiction" atau "jurisdiction to adjudicate”), yaitu kewenangan mengadili atau menerapkan hukum;

3. Jurisdiksi eksekutif ("executive jurisdiction" atau "jurisdiction to enforce"), yaitu kewenangan melaksanakan/memaksakan kepatuhan hukum yang dibuatnya.

\footnotetext{
${ }^{12}$ Masaki Hamano, "Comparative Study in The Approach to Jurisdiction in Cyber Space”, Chapter : The Principle of Jurisdiction, hlm. 1, tersedia pada cyber jurisdiction homepage, (di akses 13 mei 2017)
}

Berkaitan dengan jurisdiksi di ruang maya, Masaki Hamano membedakan pengertian "cyberjurisdiction" dari sudut pandang dunia cyber/virtual dan dari sudut hukum. Dari sudut dunia virtual, "cyberjurisdiction" sering diartikan sebagai "kekuasaan sistem operator dan para pengguna ("users") untuk menetapkan aturan dan melaksanakannya pada suatu masyarakat di ruang cyber/virtual". Dari sudut hukum, "cyberjurisdiction" atau "jurisdiction in cyber-space" adalah "kekuasaan fisik pemerintah dan kewenangan pengadilan terhadap pengguna internet atau terhadap aktivitas mereka di ruang cyber ("physical government's power and court's authority over Netusers ortheir activity in cyberspace").

Adanya upaya untuk menetapkan jurisdiksi di dunia maya, berarti akan menetapkan siapa yang memiliki hak/wewenang untuk mengatur internet. Aron Mefford, seorang pakar cyber law dari Michigan State University, mengusulkan "Lex Informatica" (Independent Net Law) sebagai "Foundations of Law on the Internet". Ide ini sepertinya diilhami oleh pemikiran mengenai "Lex Mercatoria". ${ }^{13}$

Sementara David R. Johnson dan David G. Post dalam artikelnya berjudul "And How Should the Internet $B e \quad$ Governed?" mengemukakan 4 (empat) model yang bersaing, yaitu :

1. Pelaksanaan kontrol dilakukan oleh badan-badan pengadilan

\footnotetext{
${ }^{13}$ Atip Latifulhayat, "Cyber Law Dan Urgensinya Bagi Indonesia", Makalah disampaikan pada Seminar tentang "Cyber Law" yang diselenggarakan oleh Yayasan Cipta Bangsa di Bandung, (pada 29 Juli 2000).
} 
yang saat ini ada ("the existing judicial forums");

2. Penguasa nasional melakukan kesepakatan internasional mengenai "the governance of Cyberspace";

3. Pembentukan suatu organisasi internasional baru ("A New International Organization”) yang secara khusus menangani masalah-masalah di dunia Internet;

4. Pemerintahan/pengaturan sendiri ("self-governance") oleh para pengguna Internet.

Dari keempat model tersebut, Johnson dan Post (J-P) mendukung model ke-4 ("self-governance") dan keduanya berpendapat bahwa penerapan prinsip-prinsip tradisional dari "Due Process and personal jurisdiction" tidak sesuai dan mengacaukan apabila diterapkan pada cyberspace. Menurut mereka, cyberspace harus diperlakukan sebagai suatu ruang yang terpisah dari dunia nyata dengan menerapkan hukum yang berbeda untuk cyberspace ("cyberspace should be treated as a separate "space" from the "real world" by applying distinct law to cyberspace").

$$
\text { Pendapat Johnson dan Post }
$$
tersebut, menurut Lawrence Lessiglebih merupakan suatu alasan/dalih dari perspektif normatif dari pada argumentasi analitik. Kalau pandangan "J-P" benar, bahwa dunia cyber beserta aktivitasnya harus dibedakan dari dunia riel, maka orang yang berhubungan di ruang cyber bukanlah orang yang sesungguhnya ("are notreal people"), benda/barang di ruang cyber bersifat "intangible", dan kerugian/perlukaan yang ditimbulkannya bersifat "immateriel".
Hal demikian tentunya, merupakan dalil/hal yang menggelikan ("ridiculous proposition") dan tidak benar menurut pandangan umum. Menurut Lessig, "orang tetap orang, baik sebelum dan setelah mereka menjauh dari layar komputer" (People remain people before and after they step away fromthe computer screen). ${ }^{14}$

Pandangan Johnson dan Post tidak hanya mendapat tanggapan atau kritikan dari Lessig saja, tetapi juga oleh Christopher Doran. Menurutnya pandangan mengenai tidak dapat diterapkannya jurisdiksi personal terhadap para terdakwa internet, bukanlah pandangan yang menonjol/berpengaruh. Sementara Masaki Hamano juga menyatakan bahwa ide Johnson dan Post tidak terwujud dalam kenyataan. Sekalipun banyak kasus-kasus hukum yang berhubungan dengan dunia cyber, namun Pengadilan-pengadilan di Amerika Serikat telah menerima pendekatan tradisional terhadap sengketa jurisdiksi cyberspace dari pada membuat seperangkat peraturan baru yang lengkap mengenai cyberlaw.

Barda Nawawi Arief yang setuju dengan pernyataan Masaki Hamano di atas, menyatakan bahwa :

$\begin{array}{lr}\text { "Sistem hukum dan } \\ \text { jurisdiksi } \\ \text { nasional/territorial } \\ \text { memang mempunyai } \\ \text { keterbatasan } & \text { karena } \\ \text { tidaklah } & \text { mudah } \\ \text { menjangkau } & \text { pelaku } \\ \text { tindak pidana di ruang } \\ \text { cyber yang tidak berbatas. } \\ \text { Namun tidak berarti } \\ \text { aktivitas di ruang cyber }\end{array}$

${ }^{14}$ Barda Nawawi Arief, Tindak Pidana Mayantara "Perkembangan Kajian Cyber Crime Di Indonesia" (Jakarta: Sinar Grafika ,2018),, hlm. 31-32; 


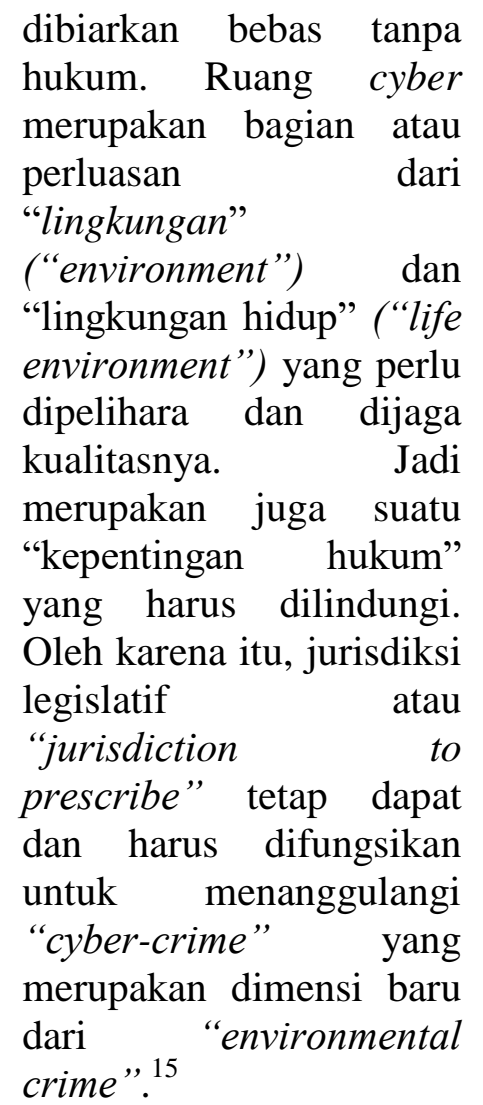

Upaya menetapkan jurisdiksi cyberspace, menurut Barda Nawawi Arief, mengapa tidak menggunakan asas universal atau prinsip ubikuitas (the principle of ubiquity). Prinsip ini pernah direkomendasikan dalam "International Meeting of Experts on The use of Criminal Sanction in theProtection of Environment, Internationally, Domestically an Regionally" di Portland, Oregon, Amerika Serikat 19-23 Maret $1994^{16}$. Asas ubikuitas inilah yang mungkin digunakan dalam jurisdiksi dibeberapa negara, seperti Australia dan USA. Undang-undang di Australia memberi kewenangan untuk menuntut seseorang dimanapun berada yang menyerang komputer di wilayahnya. Sementara di USA tidak hanya dapat

\footnotetext{
15 Barda Nawawi Arief, Tindak Pidana Mayantara "Perkembangan Kajian Cyber Crime Di Indonesia", (Jakarta: Sinar Grafika ,2018),hlm. 31-32;

16 Barda Nawawi Arief,Kapita Selekta Hukum Pidana, (Bandung, Citra Aditya Bhakti, 2003), hlm. 253;
}

menuntut setiap orang asing yang menyerang setiap komputer-komputer di USA, tetapi juga orang Amerika yang menyerang komputer di negara lain. Ketentuan ini menunjukkan bahwa komputer di pandang sebagai "kepentingan nasional" dan sekaligus juga sebagai "kepentingan internasional" yang sepatutnya dilindungi sehingga terkesan dianut prinsip ubikuitas atau asas omnipresence (ada dimana-mana).

\section{Konsepsi Internet Mobile menurut} Ahli

Penggunaan teknologi internet telah membentuk masyarakat dunia baru yang tidak lagi dihalangi oleh batas-batas teritorial suatu negara yang dahulu ditetapkan sangat esensial sekali, yaitu dunia maya, dunia yang tanpa batas atau realitas virtual (virtual reality). Inilah sebenarnya yang dimaksud dengan Borderless World. Perkembangan teknologi informasi tidak saja mampu menciptakan dunia global, namun juga telah mengembangkan ruang gerak kehidupan baru bagi masyarakat, yaitu kehidupan masyarakat maya (cybercommunity). Pada cybercomunity, semua aktivitas, interaksi, komunikasi, proses sosial, kreasi dan lain lain dapat dilakukan dengan bebas dan tanpa batas. Segala aktivitas di cyberspace seakan terlepas dari jurisdiksi nasional negara manapun, sehingga sifatnya bebas nilai.

Onno W. Purbo menyatakan bahwa internet terlihat oleh sebagian besar orang, pengguna, pengamat sosial sebagai dunia tanpa batas, dunia tanpa aturan, dunia kebebasan. Hal inilah yang menyebabkan terjadinya berbagai bentuk kejahatan dan pelanggaran di dunia maya, seperti bermunculannya 
cybercrime,cyberporn, cybersex dan lain-lain.

David Greenfield. seorang psikolog di Amerika, menemukan sekitar 6\% dari pengguna internet mengalami kecanduan. Orang-orang tersebut mengalami gejala yang sama dengan kecanduan obat bius, yaitu lupa waktu dalam berinternet. Kebanyakan orang yang kecanduan internet ini dikarenakan mereka menemukan kepuasan di internet, yang tidak mereka dapatkan di dunia nyata. Kebanyakan mereka terperangkap pada aktivitas negatif, seperti games, judi dan sex online.

Menurut Ronald Moglia dari Universitas New York, para penjaja cinta ini, baik perempuan ataupun laki-laki, setiap malam ada di jaringan internet mencari langganan baru ataupun lama Komputer dan modem telah menggantikan kaki lima dan lampu jalan sebagai tempat berjualan. Fenomena ini juga sudah mulai terjadi di Indonesia. Polda Metro Jaya pernah mengungkap adanya modus penawaran pekerja seks komersial (PSK) melalui situs poskota.net. Kasus ini merupakan fenomena yang wajar, karena internet merupakan media perdagangan (E-Commerce), termasuk dalam penawaran jasa Pekerja Seks Komersial (PSK). Sebuah message board di internet yang bertajuk "Informasi Penjaja Seks Komersial" yang dihostingkan di $e z b o * * *$.com. Isinya antara lain barter informasi yang berkaitan dengan esekesek, termasuk nama dan nomor ponsel.

Jery Repolato dalam presentasi tentang "CyberPorn and Internet Safety”, (2003) mengemukakan bahwa setiap hari ada 270 juta pengguna internet dan 68 juta atau $25 \%$ melakukan pencarian pornografi di dunia maya semakin dipermudah dengan adanya situs pencari segala bentuk informasi (web search engine), termasuk pencarian alamat-alamat situs porno. Harian USA Today edisi 28 Agustus 1997, dalam sebuah studi media yang dilakukannya, menyimpulkan bahwa $28,2 \%$ orang Amerika yang online, pernah mengunjungi situs-situs porno di internet dan $20 \%$ dari mereka menggunakan fasilitas search engine untuk menemukan situs-situs sex tersebut. Nathan Tabor mengatakan bahwa statistik menunjukan bahwa $25 \%$ dari semua internet, mesin pencarinya minta dihubungkan dengan pornografi. dan melakukan beberapa macam pencarian pornografi.

Menurut penulis ada beberapa faktor yang menyebabkan anak-anak mengkonsumsi pornografi, khususnya internet adalah :

1. Kurangnya pengawasan dan pembinaan dari orang tua kepada anak-anaknya tentang manfaat internet dan dampak negatifnya;

2. Sikap ketertutupan orang tua kepada anak-anak tentang sex education, akibatnya rasa penasaran yang begitu besar dicari jawabannya di luar rumah, seperti di warnet;

3. Orang tua yang gagap teknologi (gaptek), sehingga memenuhi kebutuhan internet untuk anak di rumah, tetapi orang tua sendiri tidak menguasainya, bahkan tidak mengetahui dampak negatif internet;

4. Kurangnya upaya proteksi oleh orang tua yang memiliki internet di rumah atau di kamar 
anak-anak, yaitu tidak melengkapinya dengan software untuk memblokir situs-situs porno;

5. Minimnya informasi dan pendidikan dari sekolah berkaitan dengan sexeducation dan dampak negatif internet dan pornografi;

6. Orientasi keuntungan finansial para pemilik warnet, sehingga siapa pun bisa menyewa internet termasuk anak-anak atau remaja, bahkan pada jamjam sekolah. Selain itu ruangan tertutup yang tersedia diwarnet menjadikan anak-anak merasa nyaman dan aman untuk membuka situs-situs porno;

7. Murahnya biaya untuk dapat mengkonsumsi bahkan memiliki fotofoto atau video porno dengan cara mendownloadnya dari sebuah situs porno dan menyimpannya pada disket, CD atau flashdisk;

8. Sikap keterbukaan masyarakat, termasuk orang tua yang sedikit demi sedikit tidak menganggap tabu hal-hal yang bersifat pornografi. Akibatnya kontrol sosial menjadi berkurang terhadap pornografi. Banyaknya peminat pornografi internet selain dapat dilihat dari banyaknya jumlah pencari situs porno, juga dapat dilihat dari jumlah anggota suatu mailing-list. Dalam mailing-list "nonaman***" di Yahoo Group.com yang ditujukan untuk peminat pornografi memiliki lebih 9000 anggota. 120 Jumlah ini jauh melebihi mailing list yang membahas teknologi informasi, seperti GENETIKA (gerakan nasional telematika) yang hanya beranggotakan 2000 orang.

Berkaitan dengan sikap keterbukaan masyarakat pada dasarnya merupakan suatu proses sosial yang dapat terjadi karena pengaruh nilai-nilai modernitas dan kemajuan teknologi yang merubah cara pandang masyarakat. Namun seharusnya pengaruh ini tetap difilter dengan norma-norma yang ada, sehingga kontrol sosial tetap berjalan, termasuk cara pandang terhadap pornografi dan seksualitas.

\section{Peraturan Perundang-Undangan Tentang Internet Mobile}

Sistem

rumusan

pertanggungjawaban pidana berkaitan erat dengan subjek tindak pidana. Dalam pandangan KUHP, yang dapat menjadi subjek tindak pidana adalah seorang manusia sebagai 144 oknum $^{17}$. Hal ini sesuai dengan Pasal 59 KUHP, dimana badan hukum/korporasi bukan menjadi subjek pertanggungjawaban pidana. Dalam penjelasan resmi (Memorie van Toelichting) Pasal 59 KUHP dinyatakan bahwa suatu tindak pidana hanya dapat diwujudkan oleh manusia, dan fiksi tentang badan hukum tidak berlaku dalam hukum pidana. Oleh karena itu, pelaku tindak pidana yang dapat dipertanggungjawabkan dalam delik kesusilaan hanya kepada individu/orang per orang saja. Sistem rumusan pertanggungjawaban pidana dalam tindak pidana kesusilaan adalah berdasarkan kesalahan atau asas culpabilitas. Hal ini dapat dilihat dengan adanya unsur kesengajaan atau kealpaan. Unsur kesalahan berupa

\footnotetext{
${ }^{17}$ Wirjono Prodjodikoro, Asas-Asas Hukum Pidana Di Indonesia, (Bandung, Eresco, 1986), hlm. 55;
} 
kesengajaan/dolus dapat dilihat pada rumusan "diketahuinya isi tulisan, gambar atau benda tersebut melanggar kesusilaan". Sementara unsur kesalahan berupa kealpaan/culpa terlihat pada rumusan "jika ada alasan kuat baginya untuk menduga bahwa tulisan, gambaran atau benda itu me!anggar kesusilaan".

Delik kesusilaan dalam KUHP menganut sistem perumusan pidana secara alternatif dan perumusan pidana pokok secara tunggal. Sistem perumusan alternatif terlihat dari rumusan ancaman pidananya, yaitu "diancam dengan pidana penjara/kurungan ... atau pidanadenda ...". Adanya ancaman pidana penjara saja menunjukkan digunakannya sistem perumusan pidana pokok secara tunggal. Jenis sanksi pidana (strafsoort) dalam delik kesusilaan di KUHP terdiri dari pidana penjara, kurungan dan denda. Ketiga jenis sanksi tersebut diancamkan untuk kejahatan kesusilaan, sedangkan pelanggaran kesusilaan hanya diancam dengan pidana kurungan atau denda. Sementara untuk lamanya pidana (strafmaat) dirumuskan secara bervariasi. Lamanya ancaman pidana penjara dalam kejahatan kesusilaan antara 4 bulan sampai 12 tahun, sedangkan pidana dendanya antara $\mathrm{Rp}$ 4.500,00 (empat ribu lima ratus rupiah) sampai Rp 75.000,00 (tujuh puluh lima ribu rupiah). Sedangkan untuk pelanggaran kesusilaan, pidana kurungannya antara 3 hari sampai 3 bulan dan pidana dendanya antara $\mathrm{Rp}$ 225,00 (dua ratus dua puluh lima rupiah) sampai $\mathrm{Rp}$ 4.500,00 (empat ribu lima ratus rupiah).

Secara eksplisit dalam KUHP tidak diatur pedoman pemidanaan. Namun KUHP yang merupakan warisan Belanda ini, menurut Sudarto memiliki pedoman pemidanaan, sebagaimana dinyatakan dalam Memorie van Toelichting dari W.v.S Belanda tahun 1886, yang isinya (terjemahannya) sebagai berikut $:^{18}$ Dalam menentukan tinggi rendahnya pidana, Hakim untuk tiapkejadian harus memperhatikan :

1. Keadaan objektif dan subjektif dari tindak pidana yang dilakukan, harus memperhatikan perbuatan dan pembuatannya;

2. Hak-hak apa saja yang dilanggar dengan adanya tindak pidana itu?

3. Kerugian apakah yang ditimbulkan?

4. Bagaimana sepak terjang kehidupan penjahat dahulunya?

5. Apakah kejahatan yang dipersalahkan kepadanya itu langkah pertama kearah jalan sesat ataukah suatu perbuatan yang merupakan suatu pengulangan dari watak jahat yang sebelumnya sudah tampak;

6. Batas antara minimum dan maksimum harus ditetapkan seluasluasnya, sehingga meskipun semua pertanyaan di atas itu dijawab dengan merugikan terdakwa, maksimum pidana yang biasa itu sudah memadai.

Sementara menurut Barda Nawawi Arief, tidak semua bangunan/konstruksi konsepsional sistem hukum pidana itu

\footnotetext{
${ }^{18}$ Sudarto, Hukum dan Hukum Pidana, (Bandung, Alumni, 1977), hlm. 55-56;
} 
dimasukkan/dirumuskan di dalam Bagian Umum Buku I, termasuk mengenai pedoman pemidanaan. Namun demikian hal ini ada didalam pelajaran/ilmu hukum pidana dan umumnya diajarkan kepada para mahasiswa hukum. Namun, karena tidak tercantum secara tegas/eksplisit di dalam KUHP, sering konstruksi konsepsional yang umum itu dilupakan; bahkan kemungkinan "diharamkan" dalam praktek atau putusan pengadilan.

Adanya pengaturan pedoman pemidanaan secara eksplisit, misalnya dalam Buku I maupun dalam penjelasan KUHP, menurut penulis pada dasarnya tidak menjadikan pengertian pedoman pemidanaan hanya sebatas pada beberapa ketentuan yang diatur dalam pedoman pemidanaan saja, karena pada dasarnya secara umum atau keseluruhan ketentuan hukum pidana yang terdapat di dalam KUHP dan Undang-undang di luar KUHP, merupakan pedoman pemidanaan.

Menurut Sudarto, tujuan pemidanaan secara tidak langsung dapat dijadikan sebagai "pedoman dalam pemberian pidana oleh hakim". ${ }^{19}$ Artinya bukan hanya ketentuan di bawah judul pedoman pemidanaan saja yang merupakan pedoman pemidanaan, tetapi termasuk pula semua ketentuan yang menjadi pedoman dalam penjatuhan pemidanaan. Berkaitan dengan hal ini, Barda Nawawi Arief menyatakan bahwa: "meskipun ketentuan tentang "perubahan/penyesuaian pidana", "pedoman penerapan perumusan tunggal/alternatif", ketentuan mengenai "pemilihan jenis pidana/tindakan", keadaan-keadaan yang dipertimbangkan untuk "tidak menjatuhkan pidana penjara", untuk "penjatuhan pidana denda", untuk "penerapan pidana minimal khusus", untuk "penjatuhan pidana terhadap anak", itu tidak berada di bawah judul "pedoman pemidanaan", namun sebenarnya ketentuan-ketentuan tersebut merupakan pedoman pemidanaan. Sementara berkaitan dengan aturan pemidanaan, memang ada perbedaan diantara keduanya, dimana pedoman pemidanaan mengandung petunjuk, sedangkan aturan pemidanaan mengandung norma. Namun demikian, secara umum keseluruhan aturan hukum pidana yang terdapat di dalam KUHP dan UU lainnya di luar KUHP, pada hakikatnya merupakan pedoman untuk menjatuhkan pidana".

Berdasarkan 2 (dua) pendapat tersebut, dapat dikatakan bahwa secara umum semua ketentuan yang terdapat di dalam KUHP dan Undang-undang di luar KUHP, merupakan pedoman pemidanaan, termasuk aturan pemidanaan. Salah satu aturan pemidanaan dalam KUHP adalah tentang aturan penjatuhan pidana denda dan denda tersebut tidak dibayar, yaitu sebagaimana diatur dalam Pasal 30 ayat (2) yang isinya menyatakan bahwa "bilamana dijatuhkan pidana denda, dan denda itu tidak dibayar, maka diganti dengan pidana kurungan”. Lamanya pidana kurungan dalam hal ini sekurang-kurangnya satu hari dan selama-lamanya 6 bulan (Pasal 30 ayat (2)). Sementara apabila ada pemberatan, maka lamanya pidana kurungan maksimal adalah 8 bulan (Pasal 30 ayat (6)).

\footnotetext{
${ }^{19}$ Sudarto, Hukum dan Hukum Pidana, (Jakarta: Sinar Grafika ,2018), hlm. 50;
} 


\section{Aspek Pidana Dalam Internet Mobile}

Delik kesusilaan dalam KUHP menganut sistem perumusan pidana secara alternatif dan perumusan pidana pokok secara tunggal. Sistem perumusan alternatif terlihat dari rumusan ancaman pidananya, yaitu "diancam dengan pidana penjara/kurungan ... atau pidana denda ...". Adanya ancaman pidana penjara saja menunjukkan digunakannya sistem perumusan pidana pokok secara tunggal. Jenis sanksi pidana (strafsoort) dalam delik kesusilaan di KUHP terdiri dari pidana penjara, kurungan dan denda. Ketiga jenis sanksi tersebut diancamkan untuk kejahatan kesusilaan, sedangkan pelanggaran kesusilaan hanya diancam dengan pidana kurungan atau denda. Sementara untuk lamanya pidana (strafmaat) dirumuskan secara bervariasi. Lamanya ancaman pidana penjara dalam kejahatan kesusilaan antara 4 bulan sampai 12 tahun, sedangkan pidana dendanya antara $\mathrm{Rp}$ 4.500,00 (empat ribu lima ratus rupiah) sampai $\mathrm{Rp} \mathrm{75.000,00} \mathrm{(tujuh}$ puluh lima ribu rupiah). Sedangkan untuk pelanggaran kesusilaan, pidana kurungannya antara 3 hari sampai 3 bulan dan pidana dendanya antara $\mathrm{Rp}$ 225,00 (dua ratus dua puluh lima rupiah) sampai $\mathrm{Rp}$ 4.500,00 (empat ribu lima ratus rupiah).

Maraknya pornografi dan pornoaksi yang beredar bebas di masyarakat melalui berbagai media dengan dampak negatifnya yang luas dan dalam upaya perlindungan perempuan dan anak-anak serta masih lemahnya kebijakan hukum pidana saat ini dalam upaya penanggulangannya, terutama pemberantasan cyberporn, maka kriminalisasi pornografi dan pornoaksi dalam RUU APP merupakan suatu kebutuhan dalam rangka perlindungan masyarakat dan penataan kehidupan sosial yang sesuai dengan nilai-nilai agama dan moral.

Adanya kriminalisasi internet dalam Konsep KUHP 2005 ini merupakan suatu upaya antisipasi dan penanggulangan maraknya pornografi di dunia maya. Dalam proses kriminalisasi ini perlu memperhatikan sebab-sebab timbulnya dampak negatif dari internet mobile yang meliputi berbagai aspek, seperti aspek ekonomi, sosial budaya dan adanya kelainan atau penyimpangan perilaku seks. Selain itu, upaya preventif dan aspek perlindungan korban, moralitas pelaku, anak-anak dan masyarakat umum juga penting, baik menggunakan sarana penal maupun non penal.

\section{PENUTUP}

\section{Simpulan}

Berdasarkan pembahasan dalam hasil penelitian dan analisis data di atas, penulis mengambil kesimpulan sebagai berikut :

1. Dampak negatif penggunaan internet mobile di Indonesia diciptakan sebagai media untuk menyebarkan segala bentuk data yang bernilai positif. Namun, internet kini telah beralih fungsi sebagai media penyebarluasan hal-hal yang merugikan. Berikut beberapa dampak negatif penggunaan internet: pornografi, kecanduan hubungan maya, perjudian, informasi berlebih, kekerasan, penculikan, pelecehan cyber, perdagangan pasar gelap cyber, dan hacking data security. 
Selain dari itu, dampak negatif internet bisa berakibat pada faktor ekonomi seseorang.

2. Upaya hukum untuk mencegah dampak negatif teknologi informasi di Indonesia, yaitu mengambil langkah kebijakan hukum dengan membuat undangundang yang dapat menjerat pelaku kejahatan teknologi informasi. Selain dari hal itu Menghimbau negara anggota untuk mengintensifkan upayaupaya penanggulangan penyalahgunaan komputer yang lebih efektif dengan mempertimbangkan langkahlangkah sebagai berikut : melakukan modernisasi hukum pidana materiel dan hukum acara pidana, mengembangkan tindakan-tindakan pencegahan dan pengamanan komputer, melakukan langkah-langkah untuk membuat peka (sensitif) warga masyarakat, aparat pengadilan dan penegak hukum terhadap pentingnya pencegahan kejahatan yang berhubungan dengan komputer, melakukan upayaupaya pelatihan (training) bagi para hakim, pejabat dan aparat penegak hukum mengenai kejahatan ekonomi dan Memperluas "rules of ethics" dalam penggunaan komputer dan mengajarkannya melalui kurikulum informatika, mengadopsi kebijakan perlindungan korban sesuai dengan deklarasi PBB mengenai korban, dan mengambil langkah- langkah untuk mendorong korban melaporkan adanya kejahatan teknologi informasi, menghimbau negara anggota meningkatkan kegiatan internasional dalam upaya penanggulangan dampak negatif teknologi informasi, merekomendasikan kepada Komite Pengendalian dan Pencegahan dampak negatif teknologi informasi

3. Sanksi dan peraturan pidana yang dapat digunakan untuk menjerat pelaku kejahatan teknologi informasi. Jenis sanksi pidana dalam tindak pidana pornografi ada 2 (dua) jenis, yaitu pidana penjara dan pidana denda. Jumlah Pidana denda, yaitu antara Rp.300.000.000,- sampai dengan Rp 3.000.000.000,- hendaknya dapat dikaji kembali, karena terus meningkatnya keuntungan yang diperoleh korporasi dalam teknologi informasisaat ini, khususnya pada sebuah situs porno.

\section{Saran}

Berdasarkan hal-hal tersebut di atas, maka dapat disarankan sebagai berikut :

1. Dalam upaya pencegahan dampak negatif teknologi informasi dan komunikasi di Indonesia hendaknya hendaknya di buat peraturan yang khusus mengenai kejahatan internet mobile sehingga para aparatur hukum dan pihak yang terkait bisa menindak tegas pelaku kejahatan teknologi informasita. 


\section{DAFTAR PUSTAKA}

Bungin, M.Burhan, Pornomedia "Sosiologi Media, Konstruksi Sosial Teknologi Telematika dan Perayaan Seks di Media Massa", (Jakarta : Prenada Media, 2014).

Chazawi, Adami, Tindak Pidana Mengenai Kesopanan, (Jakarta : Raja Grafindo Persada, 2016).

Desmon Asiku, Achmad, Cybersex : Finally Exposed, (Jakarta : Mahenjo Daro Publishing, 2010).

Faulidi Asnawi, Haris, Transaksi Bisnis ECommerce Perspektif Islam, (Yogyakarta : Magistra Insania Press, 2011).

Hamzah, Andi, Aspek-Aspek Pidana di Bidang Komputer, (Jakarta : Sinar Grafika, 2013).

Lamintang, Delik-Delik Khusus : Tindak Pidana-Tindak PidanaMelanggar Norma Kesusilaan dan NormaNorma Kepatutan, (Bandung : Mandar Maju, 2015).

Lampeter, Gary R. Bunt, Islam Virtual : Menjelajah Islam di Jagad Maya, (Yogyakarta : Suluh Press, 2010).

Mahmud Marzuki, Peter, Penelitian hukum, (Jakarta : Prenada Media, 2017).

Marpaung, Leden, Kejahatan Terhadap Kesusilaan Dan Masalah Prevensinya, (Jakarta : Sinar Grafika, 2016).

Muladi dan Barda Nawawi Arief, Teori-teori dan Kebijakan Pidana, (Bandung : Alumni, 2013).

M. Ramli, Ahmad, Cyber Law dan HAKI dalam Sistem Hukum Indonesia, (Bandung : Refika Aditama, 2012).

Raharjo, Agus, Cybercrime "Pemahaman dan Upaya Pencegahan Kejahatan Berteknologi”, (Bandung : PT.Citra Aditya Bakti, 2013).

Yudhista, Doddy dan Tim MWCC, Teknologi Informasi dan Pembangunan Demokrasi di Indonesia, (Jakarta : Habibie Center, 2012). 